\title{
Blue Economy of Bangladesh: Opportunities and Challenges for Sustainable Development
}

\author{
Md. Khairul Islam \\ Graduate student, Department of Economics \& Banking, \\ International Islamic University Chittagong. \\ Mahbubur Rahaman \\ Faculty, Department of Business Administration, \\ International Islamic University Chittagong.

\section{Zobayer Ahmed} \\ Faculty, Department of Economics \& Banking, \\ International Islamic University Chittagong.
}

\begin{abstract}
The blue economy refers to the economic activity based on maritime resources. The paper aims to explore the current scenario of sea resources of Bangladesh. Using secondary data, the study reveals that Bangladesh can accelerate its economic growth through the sustainable use of the sea resources. Moreover, Bangladesh has $710 \mathrm{~km}$ long coastline with 200 Nautical Miles of an exclusive economic zone inside the Bay of Bengal. Marine fisheries contribute $19.4 \%$ of the total fish production of the country. Besides, the western coastline of Cox's Bazaar is the longest sea beach in the planet that is visited by on an average, $81 \%$ of the international tourists arrive in Bangladesh. However, due to lack of institutional capacity and given the socio-cultural context, the sustainability of the sea resources is now facing critical threats. Apart from studying the present status of sea resources, the paper proposed some way forwards based on existing opportunities and challenges for promoting sustainable development in Bangladesh.
\end{abstract}

Key Words: Blue Economy, Bay of Bengal, Bangladesh, Sustainable Development, Longest Sea Beach.

\section{INTRODUCTION}

Blue Economy as an idea was first introduced by Professor Gunter Pauli in 1994. It achieved large amount of attention only in recent 2012 Rio+20 Conference. Blue Economy in Bangladesh is often mistaken as only the economic activities which taken place on ocean. Certainly oceanic economic activities are integral parts of Blue Economy but not all kinds of oceanic activities and not only oceanic activities are Blue Economy. A total of 26 marine economic functions can be recognized as integral part of the Blue Economy. Among them fishery, maritime trade and shipping, energy, tourism, coastal protection, maritime monitoring and surveillance are worth to note. Blue Economy as a philosophical economic movement acknowledges some aspects of popular concept of "green living", such as using organic food and applying certain forms of renewable energy, can be financially out of reach for significant part of the people in the society. The primary target of the Blue Economy is to establish the examples from nature where organic recycling occurs and stimulates these processes to find out where and how the waste that generated from various anthropogenic sources can be innovatively made useable again. 
Blue economy is characterized as appropriate use of marine assets that entirely reduce ecological hazard and enhance human prosperity. It contains all economic exercises related with the seas, ports coastal zones and others ocean-based exercises. It has center commitment in the socio-economy and identified with ocean-borne exchange and business, seas science and such other economic activities. Nationally and universally it helps to the nations which are utilizing marine assets. The point of this economy is to plenitude of shortage in the country. Two-third of the earth land is under the water and Bangladesh is additionally a riverine nation. In this way, blue economy can contribute deeply in the improvement of economic development and social welfare on it.

'Blue Economy' was considered at the RIO + 20 United Nation (UN) Conference on sustainable development, held in Rio de Janeiro, Brazil in June 2012. The sea is the best sources of energy utilization. At present, a large portion of the nations is trying to ensure the most extreme utilization of the sea for the sustainable improvement. As their economy is now becoming Ocean based economy and the ocean is blue that's why the oceanic based economy is called the blue economy.

It is one of the critical factors contributing to the socio-economic development of coastal nations. At present, Bangladesh has picked up a large area in the Bay of Bengal through the settlement of sea debate with India and Myanmar. Presently, Bangladesh can claim to be a nation of blue economy. This sea settlement has preferred Bangladesh with the extension of regional territory and Economic Zone. The geographical zone involves more than 1, 18,813 square kilometers of water including 200 nautical miles over the sizeable range since the settlement of the suit has opened an incomprehensible open door for our nation, the various discussion is going ahead with emphasizing on cultivating the procedures of how using the capability of our new ocean economy. The Bay of Bengal can rise as a profoundly prospective source of the Blue Economy. Bangladesh can take benefits of its ocean-borne assets like oil and gas investigation, fisheries, shipbuilding and shipbreaking, salt collecting, creating tourism and so on.

The world has been racked by food, fuel, natural, economical and money related crises. A blue economy can bargain systematically with these difficulties. It is a unique vision of what is conceivable with regards to the practical economy. The blue economy assumes a vital part for our nation. Since over $70 \%$ of our planet is secured by the sea and around $90 \%$ of the world's exchange of products is directed via ocean. The fact that our nation has won the large maritime boundary. It has made large scopes to investigate mineral resources from the seabed without obstacles. A great supply of living and non-living assets is available under the seabed and water section. In any case, we have a shortage of skilled labor to determine the availability and investigate the assets. To manufacture skilled labor in these segments, we have found a way to import advanced education on oceanography in Bangladesh.

It's high time that Bangladesh set up to utilize the ocean assets and fitted its labor with learning and innovation to bring success to the country. The rising ocean level and saltiness are two significant difficulties to the seaside populace, and we need to upgrade our ability to secure ourselves in such circumstance. We expect that the blue economy will make another skyline of expectations and desires to transform Bangladesh into a developed nation.

The blue economy concept was perhaps unknown in Bangladesh. But after the settlement of sea limit border question with Myanmar and India discussion started on the blue economy. The general verdict helped Bangladesh setting up sovereign rights over the living and non-living assets of the Bay of Bengal inside $200 \mathrm{~nm}$. Similarly, the decision with India declared on 
seventh July 2014. Bangladesh's economy is ocean-borne to a proper extent, and with \$ 130 billion GDP the nation's economy stands the 44th position in the world. Focusing the significance of blue economy, Prime Minister Sheik Hasina (on first September 2014 in the global workshop on the blue economy in Dhaka) said that marine-based economic activities and administration of ocean and its assets through "Blue Economy" could make new skyline for the improvement of a coastal nation like Bangladesh. At present, $90 \%$ of the nation's exchange is transported through the ocean. The fisheries and others mineral assets in the Bay of Bengal can contribute enormously to the economy of Bangladesh. Marine fishes are one of the valuable export items of Bangladesh. It is now more appropriate to depend on sea assets and management of sea resources through the blue economy.

The primary objective of this study is to investigate the current scenario of the sea-based economy in Bangladesh. The contribution of this study is that it discusses the other sectors like tourism along with the fishing and aquaculture sectors with recent data.

\section{LITERATURE REVIEW}

The concept of the blue economy is new in Bangladesh, not the international border. For this reason, there are not much research works on this concept. But recently, it achieved much attention from researchers around the world. This term was introduced by Gunter Pauli (Pauli, 2010) and later became popular after the United Nations Conference on Sustainable Development held in Rio de Janeiro in 2012 (Smith-Godfrey, 2016). The term 'Blue Economy' does not have any universally accepted definition (Bollmann 2010). However, from the literature, it can be understood that blue economy tries to utilize the oceans and coastal resources in a proper way.

Jiang, Liu, and Su (2014) estimated a multi-factor production function model with a constant elasticity of substitution in the case of China's marine sector. They found that during 2000 to 2011, the contribution of the Chinese marine economy to the country's GDP raised from 6.46\% to $13.83 \%$, with an average annual growth rate of $7.17 \%$. Zhang, Dong, Yang, Wang, and Song (2004) suggested some policies to achieve the sustainable development of sea economy in China that include- 1) To make ocean strategies as national strategy, 2) To achieve combined economic growth of sea and land; 3) To develop marine resources by science and technology; 4) Establish suitable legal institution for marine environment; 5) To create new idea of sea defending. On the other hand, Nuryadin, Syaifudin, Handika, Setyobudi, and Udjianto (2016) investigated the contribution of the blue economy in the economy of Indonesia. They found that the marine sector contributes $7.86 \%$ to the economy. Further, they recommended that fish assets, maritime industry, marine set-up and marine services are the major sectors that have very possibility for development.

Many researchers also investigated the contribution of tourism to economic development. Tourism industry can positively influence the economic growth, tourists expenditure and thus increase the potential growth in the economy_ENREF_1. Ghali (1976) investigated the tourismled growth hypothesis in the case of Malaysia and Singapore. They found that tourism is the cause for economic growth in Singapore, but economic growth is cause for tourism in Malaysia. Samimi, Sadeghi, and Sadeghi (2011) estimated the relationship between economic growth and tourism industry in the developing countries. They found that tourism is also one of the reasons for economic development in those developing countries. Tugcu (2014) explored the relationship between tourism growth and economic growth in many Asian, African and European countries. They found that European countries are better able to produce income from the tourism sector. There is also other research that did not see the relationship between tourism and economic growth. Ahmed, Allison, and Muir (2010) examined freshwater prawn 
farming in Bangladesh they found that the average annual production of prawn, fish, and rice was estimated at 467, 986 and 2,257 kg ha-1, respectively. They also found that large farmers produced higher production because of economies of scale with more inputs. They further found that the larger farm size and the long experience of prawn farming have a positive impact on production. However, there is no specific study conducted in case of Bangladesh that analyzes the contribution of sea resources in the economy from a sustainable development perspective.

\section{METHODOLOGY}

This study applied descriptive statistics to present the current scenario of the blue economy in Bangladesh. Graphical inspection is a common and useful technique to observe the trend and behavior of any variable. This study inspects the trends in some variables through graphical examination. The variables used in this study are: 1) Export receipt from fish and prawn in Bangladesh. 2) Export receipt from fish and shrimp of Bangladesh 3) Tourism arrival in Bangladesh.

The secondary data and other information used in this study have been collected from two main sources- 1) The Bangladesh Bank and 2) World Bank.

\section{Blue Economy and Sustainable Development}

In simple, the development of blue economy not solely the development of ocean economy. However, property development of the marine economy is also included in the development considerations. Thus, blue economy and property development square measure inter-related. According to the often-cited Bruntland Report issued by the World Commission on Environment and Development (1987), 'Development that meets the wants of the current while not compromising the possibility of future generations to satisfy their own needs' (Keeble,1988).

Globally we have a tendency to be even meeting the wants of the current not to mention considering the requirement of future generations. Since, coastal regions and developing Island countries have continued at the front position of this Blue Economy, recognizing that the oceans have a significant role to play in humanity's future. Therefore, we should always take into account Blue Economy within the context of property development and impoverishment wipeout joined of the necessary tool obtainable for achieving property development. There is a tendency to emphasize that, it ought to contribute to removing impoverishment likewise as sustained economic process, improving social inclusion, boost up human welfare and making opportunities for the generation of employment opportunity and tight work for all whereas continuing the strong functioning of the earth's scheme Para fifty six, the long run we would like (UNCHD, 2012).

As per the Article 56 of the United Nations Conventions on the Law of the Sea (UNCLOS), the coastal country (Bangladesh) has authority over the formation and use of artificial islands, installations and constructions; naval scientific research; security and conservation of the marine environment and Article 77 states sovereign rights in the Exclusive Economic Zone (EEZ) for the intention of discovering and exploiting, preserving and managing the natural resources, whether non-living or living, of the waters superjacent to the seabed and its subsoil, and with regard to other deeds for the economic exploration and exploitation of the zone, such as the production of energy from the sea water, currents and winds. 


\section{Marine protected areas (\% of territorial waters) in South Asia.}

Marine protected areas are preserved areas bylaws. Figure-1 shows that Bangladesh has 2.5 percent protected areas out of all territorial water-lands.

Figure-1: Percentage of territorial waters as marine protected areas

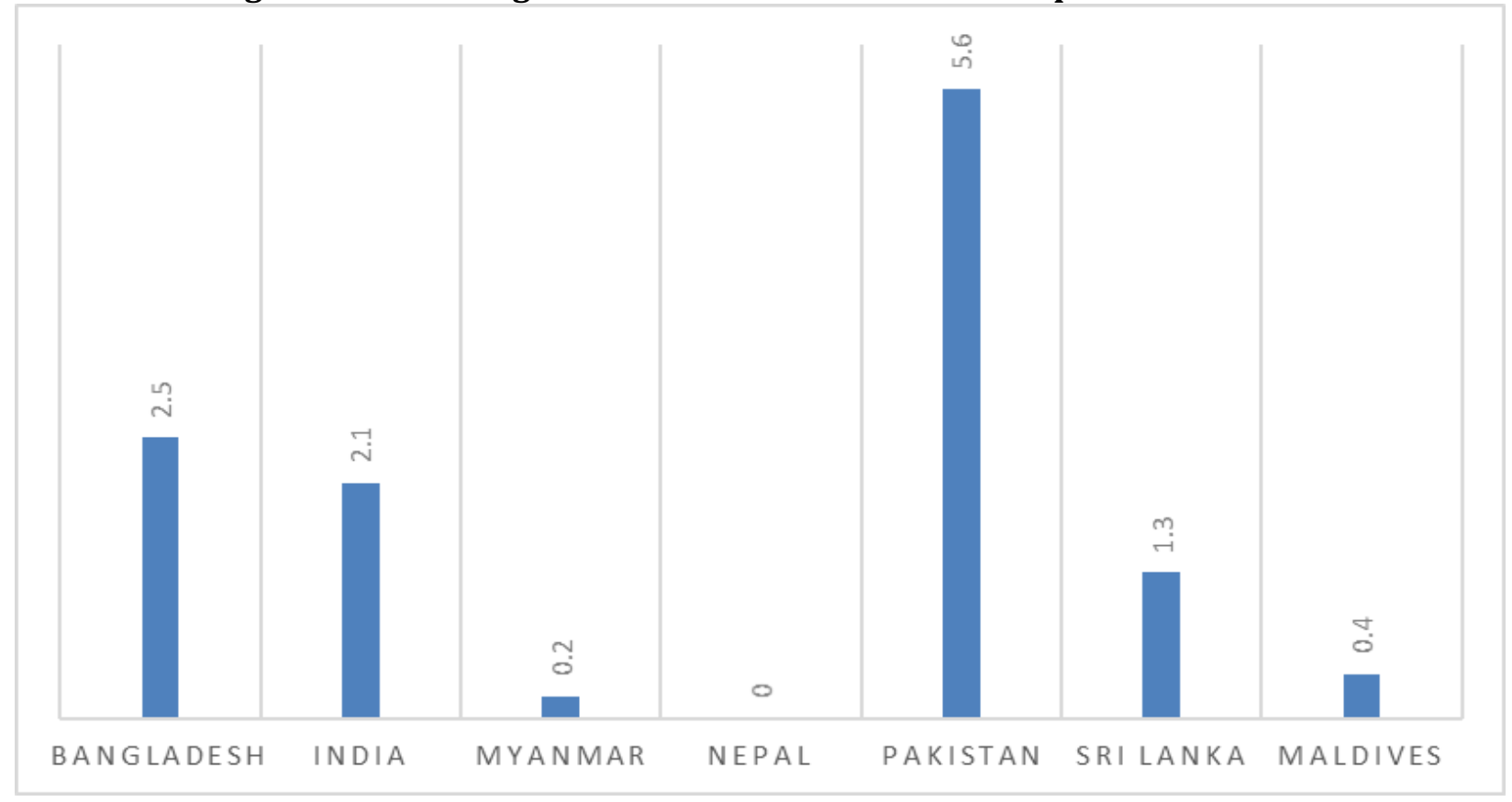

Data sources: OECD

\section{Blue- tourism destinations in Bangladesh}

Tourism which is one of the sectors of the blue economy in Bangladesh has been recognized as one of the most gainful business and the key to worldwide trades. Bangladesh has an incredible open door and capability of turning into a tourist based country. Tourism industry gives more openings for work when contrasted with different ventures. Tourism business reduces unemployment and helps to earn more foreign exchanges.

Consistently plenty of worldwide travelers visit Bangladesh, and the quantity of visitor are expanding step by step. Without a doubt, Bangladesh gets less global visitor than India and Nepal. However, the circumstance is evolving quick, in light of simple correspondence with the world. The public airplane terminal has an association with critical air terminals of the world. The administration of tourism suppliers is exceptionally proficient at this point. There are a ton of lodgings, motels to suit visitors. Furthermore, now one vital thing is the tourism-related administrations spread to many places similarly to what was inaccessible to remote regions already.

Cox's Bazar: Cox's Bazar (named after British East India Company officer, Captain Hiram Cox 1799 ) is the first candidate amongst the tourist's destination in Bangladesh. It is a fishing port as well. The sea beach in Cox's Bazar has an unbroken $120 \mathrm{Km}$ sandy sea beach which is considered as one of the longest sea beaches in the world. At present, Cox's Bazar is one of the most-visited tourist destinations in Bangladesh.

St. Martin: This coral island has been the popular attraction of local and foreign tourists in Bangladesh. The majority of its inhabitants live primarily from fishing. One can reach St. martin-island within few hours from Teknaf in a short time. The number of visitors has 
increased sharply in recent years. It is considered one of the eco-tourism destination in Bangladesh.

Kuakata: Kuakata is located in Kalapara Upazila, Potuakhali District. It is about 320 kilometers (200 mi) south of Dhaka, the capital, and about 70 kilometers (43 mi) from the district headquarter. Kuakata has an excellent view of the sunrise and sunset from the same white sandy beach in the water of the Bay of Bengal. The long strip of dark, marbled sand stretches for about 18 kilometers (11 mi). This sandy beach has gentle slopes into the Bay of Bengal. Many migratory winter birds are staying in Kuakata. However, because of the poor transport facilities to trip to Kuakata, it has fewer visitors than cox's bazar.

\section{Fish Export from Bangladesh}

The Table 1 and figure 2 show that the export receipt from fish and prawn are increasing and on average Bangladesh received 252.95 cores taka between 1972 and 1992. Data are collected from Bangladesh Banks's time series database. However, during 1993-2015 the average receipts are 2615 cores taka. It is clear from figure 4 and figure 5 that, the fish export receipts have upward trends which indicate that Bangladesh is earning more and more from fish exports. However, during 2008-2009 it has declined sharply and then again increased. The deviation from trend might be due to the political unrest and the floods during 1998.

Table 1: Summary statistics for export receipts from fish and pawn during 1972-1992. Source: Bangladesh Bank.

\begin{tabular}{|l|l|}
\hline & FISH_EXP Tk. Cores \\
\hline Mean & 252.9524 \\
\hline Median & 182.0000 \\
\hline Maximum & 794.0000 \\
\hline Minimum & 2.000000 \\
\hline Std. Dev. & 251.8951 \\
\hline Sum & 5312.000 \\
\hline Sum Sq. Dev. & 1269023. \\
\hline Observations & 21 \\
\hline
\end{tabular}

Figure 2: Trend in export receipts from fish and prawn for the period 1972-1992.

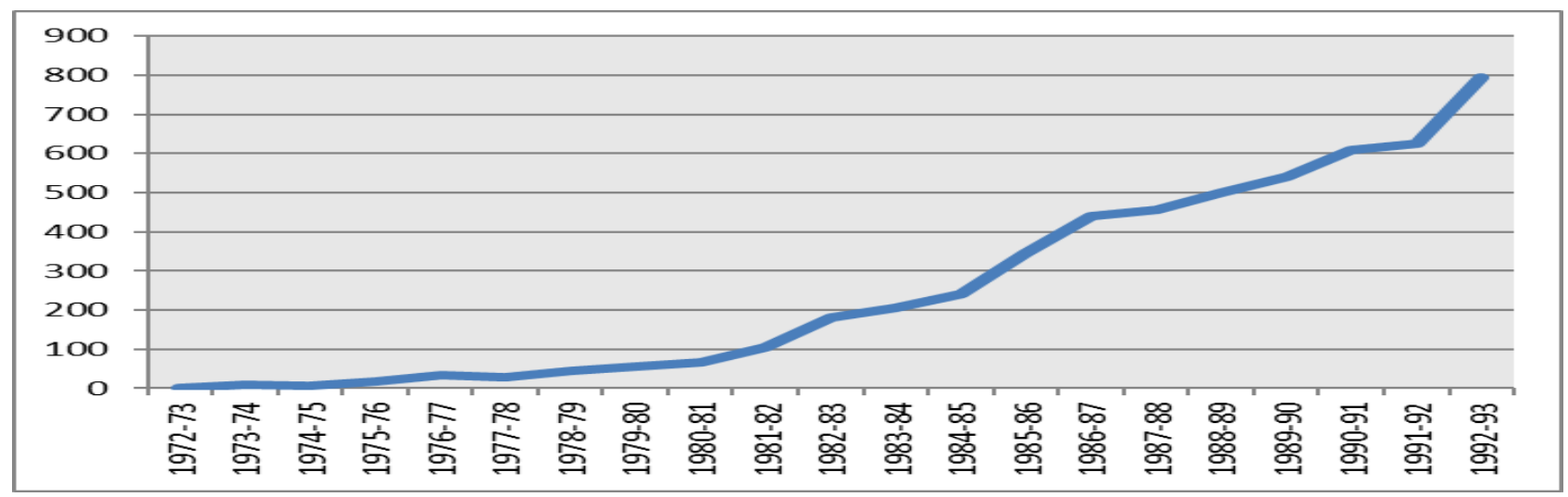

This following table shows that, the average export receipts from fish and shrimp from (19942015) Tk. 2615.500 Cores. The maximum amount received from this sector Tk.4758.000 cores. 
Table 2: Summary statistics for export receipts from fish and shrimp during 1994-2015.

\begin{tabular}{|l|l|}
\hline & FISH_EXP ORTS 1994-2015 \\
\hline Mean & 2615.500 \\
\hline Median & 2430.000 \\
\hline Maximum & 4758.000 \\
\hline Minimum & 1013.000 \\
\hline Observations & 22 \\
\hline
\end{tabular}

Source: Bangladesh Bank.

In this graph indicates that, export receipts from fish and prawn for the period of 1993-2014. From 1993-2001 the received increased with up-word sloping. In 2011-2012 the revenue was highest.

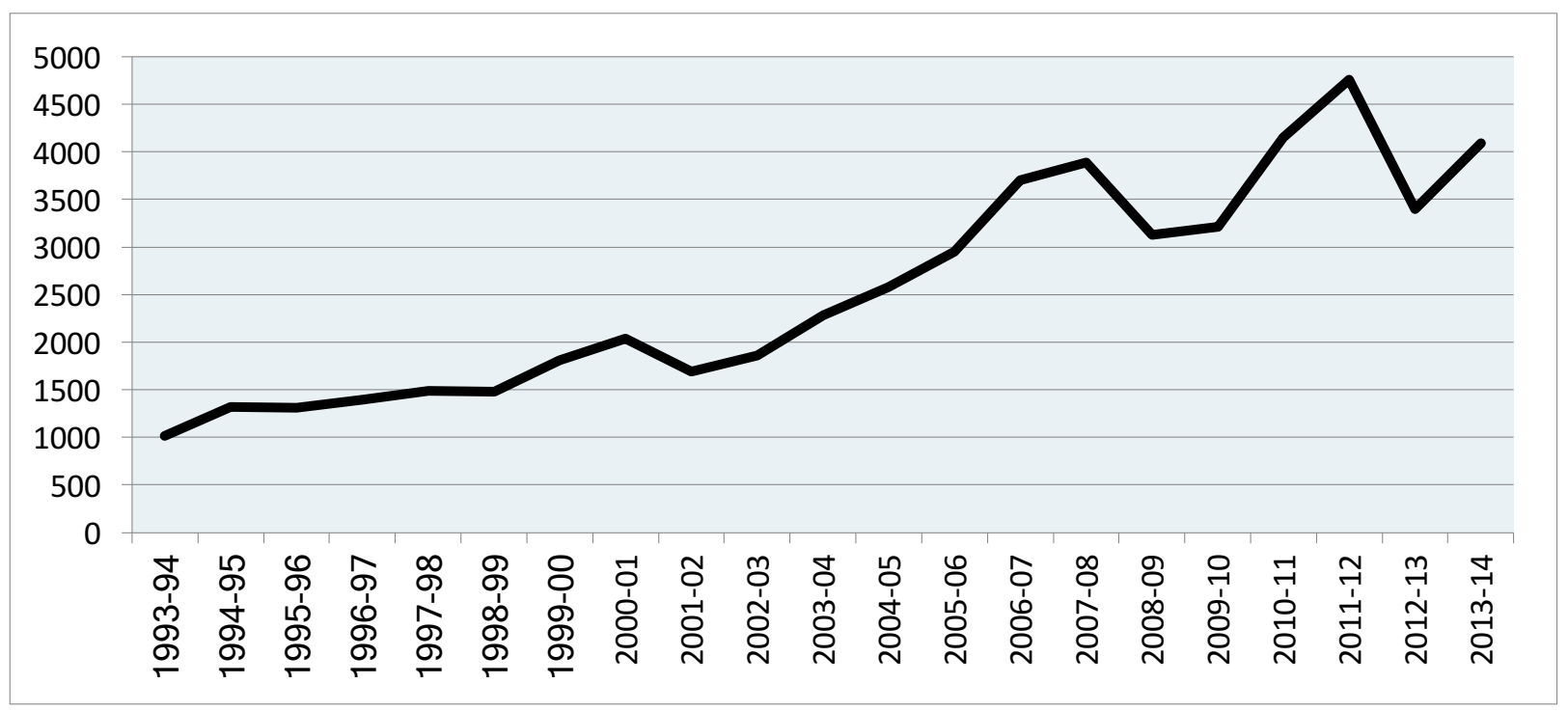

Figure 3: Trend in export receipts from fish and prawn for the period (1993-2014).

Total Fisheries production in Bangladesh 1972-2014

Table 4 shows that in Bangladesh fisheries production from 1972-2014 the maximum output is 3548115 and average production is 1458879 .

\begin{tabular}{|l|l|}
\hline \multicolumn{1}{|c|}{ Items } & \multicolumn{1}{c|}{ FISHERIES_GDP } \\
\hline Mean & 1458879. \\
\hline Median & 1002567. \\
\hline Maximum & 3548115. \\
\hline Minimum & 640070.0 \\
\hline Std. Dev. & 905711.4 \\
\hline Observations & 43 \\
\hline
\end{tabular}


Figure 3: Total Fisheries production in Bangladesh 1972-2014 in the metric ton

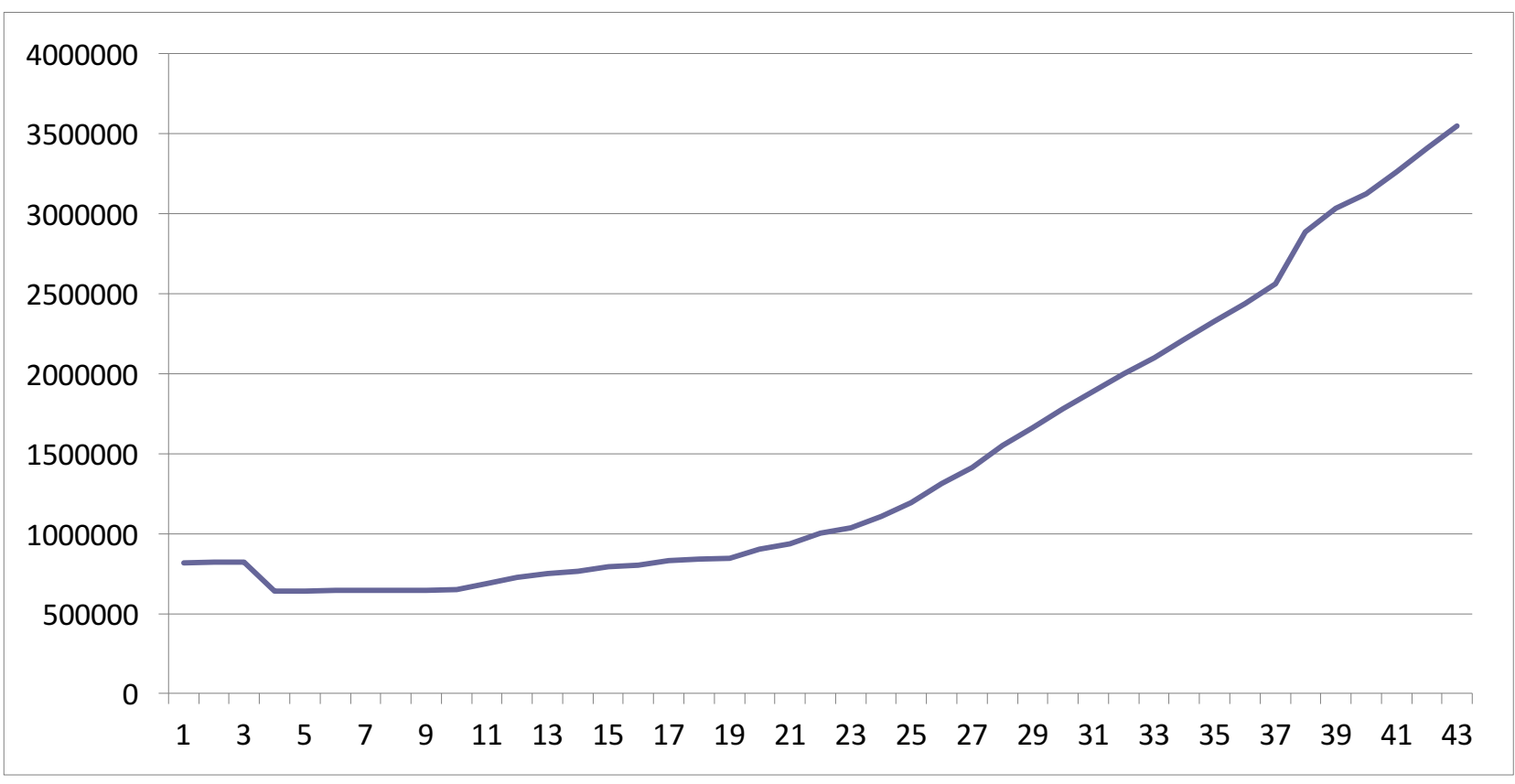

\section{Opportunities for Blue Economy Expansion in Bangladesh}

South Asian countries area uniquely blessed the Bay of Bengal, the most crucial Bay within the world deckled by Bangladesh to the North, India to the west. It has vast potentials for the Blue Economy.

The productive economic sectors of blue economy area unit emphasized and regarded in harnessing the total utilization of ocean-based resources primarily inside the current maritime boundary of Bangladesh. If this ocean mostly based resources area unit managed by correct coming up with and inter-sectoral coordination of public-private partnership and investment, it'll generate a sturdy foundation for earnings and economic advantages below the approach of blue economy. On the opposite hand, if marine primarily based financial resources with potential sectors are managed and ruled by principles of diversity protection, conservation and efforts for care area unit tangled with a vision of scientific understanding, so the blue economy will produce some opportunities to resolve the problems of climate changes at the coastal areas. It would additionally generate jobs and convey concerning tangible changes within the lives and keep off the immeasurable folks living on the outline, in islands, and across Bangladesh. A coordinated approach with involved stakeholder's teams is needed to see the extent to that the constraints mentioned within the discussion section may be changed into opportunities, and to make sure that development of the blue economy doesn't end in unsustainable and damaging practices for the good thing about short-term economic gains over longer terms property economic and social advantages. Specifically, for Bangladesh, this involves developing a maritime/marine spatial coming up with the directive to detail coordination between blue economy sectors and stakeholders to make sure property development.

\section{Potential Blue Economy Sectors of Bangladesh}

Shipping: Coastal nations ought to position themselves concerning facilities to catch up for this developing exchange and optimize their advantages. The ship is safest, most secure, additional productive and ecologically stable for modification of any product from one country to a different. Apart from Chittagong and Mongla seaports, there is a high potentiality of establishing deep sea port at Sonadia island of Cox's Bazar. 
Fisheries: Fisheries is a significant economic sector in nations with coasts on the Bay of Bengal geographical region, viz. Sri Lanka, India, Bangladesh, Myanmar, Thailand, Malaya, and country. Fish is that the most demandable animal primarily based supermolecule in the food of the overall population in these countries. It is the smallest amount concerned by culture and religions. In light-weight of a current estimate, the combination variety utilized on a full-time basis in fisheries within the space lined by the Bay of the geographical region (BOBP) is one.85 million. Globally 350 million jobs are connected to marine fish, with ninety percent of fishers living in developing countries.

Tourism: Marine and coastal business enterprise are significance to several developing nations. Business enterprise could be a major worldwide industry; in 2012 universal economic crises by four despite the global financial crises and grooved Sep 11 of extensive gross domestic product. In 2012 business enterprise support Sep 11 of world occupations and created 6 June 1944 of the planet export profits.

Energy: In 2009 offshore fields drawn thirty second of overall rock oil production and this project could ascend to thirty-fourth in 2025 , as an oversized portion of the retrievable formal oil is evaluated to be in seaward fields-a fourth of that in the problem.

Biotechnology: The worldwide marketplace for biotechnology things and procedures is correct currently calculable at $\mathrm{U} \$$ two.8 billion and grow to develop to around U\$ four.6 billion by 2017. Marine biotech has the potential to deal with a suite of global difficulties, to Illustrate, property food provides, human health, energy security, and natural remedy.

Submarine mining: The planet is getting ready for the exploration and exploitation of mineral stores on and beneath the ocean floor. Industry, owing to increasing product worth, is popping its attention to the potential wealth of nodules, cobble and then on. Business profit is substantial in buds.

Harvesting Power Generation: Researchers have recently completed the primary ocean tests of a system that uses an artificial muscle to come up with power from the motion of a float riding up and down on the waves. Though the example produces little electricity, the researchers say that wave forms supported the technology may eventually rival wind turbines in power output that provides a significant supply of fresh energy and will massively contribute profit, an influence hungry nation.

Shipping and port facilities: $80 \%$ of the world trade by volume, and over $70 \%$ by worth, is carried by the ocean and handled by ports worldwide. For developing countries, these percentages are generally higher. World free trade grew by $4 \%$ in 2010 despite the economic recession.

\section{Challenges for Sustainable Development of Blue Economy}

The role of marine assets in economic condition reduction, autarchy in food productions, securing natural balance, facing opposite effects of environmental amendment et al. economic potential outcomes area unit unlimited. However with the chances and possible outcomes the difficulties conjointly companion. Future may well be the difficulties:

* The absence or severe lack of 'proper policy' and 'marine related peoples/resource persons' at higher policy levels and similar national organizations/body in relevant ministry/department is a significant drawback for the implementation of many issues related to the capacity development of different marine sectors in Bangladesh. 
* We have to be compelled to guarantee our sovereignty over the entire coastal space \& maintaining the safety over the commercial coastal area of the Asian nation.

* The authority should be controlled water level rise and alter in system and temperatures, from coral bleaching.

* Lack of knowledge, expert workforce, and technology to take maximum benefits from the blue economy, especially for exploiting deep-sea fishes and seabed resources.

* Lack of cordial combination of visionary political leadership, efficient bureaucracy, investors of real entrepreneurial attitude and innovative development thinkers to succeed in that plan.

* We have no robust master plan which will be focused on the entire coastal belt and targeting extra-regional players.

* Establishing marine friendly infrastructure for marine tourism.

* Keeping up an investment-friendly environment in the specific area.

* Economical utilization of biodiversity.

* Safeguarding mangrove and ocean grass.

* Addressing environmental change and managing carbon discharge.

* Preventing acidification of waters.

* Keeping ocean region free from pollution.

\section{CONCLUSION}

It can be concluded that Bangladesh needs at this moment to create more awareness and broaden the horizon towards utilizing maritime resources and bring about socio-economic changes in the lives of people of Bangladesh. Waters surround the country from three parts, and it has many rivers. The blue economy can be one of the possible solutions for Bangladesh to achieve sustainable economic growth. This study attempted to present the current scenario of the blue economy in Bangladesh. From the analysis, we found that the sea production and aquaculture production is increasing. It is a good sign. However, frequent floods in Bangladesh are damaging the possibilities of blue sectors. Without having well-trained, skilled and educated human resources in different marine industries, sustainable and dynamic blue economy is not possible for any country. The coastal areas like Cox's Bazar, St. Martin, Kuakata can contribute much to the economic development of Bangladesh if we can use these resources appropriately.

The government should take future policy-framework for the success of the Blue Economy which may focus on structural collaboration; translating research in products, holistic approach to the Blue Economy; and motivating \& training young generations.

\section{References}

Ahmed, N., Allison, E. H., \& Muir, J. F. (2010). Rice fields to prawn farms: a blue revolution in southwest Bangladesh? Aquaculture International, 18(4), 555-574.

Ghali, M. A. (1976). Tourism and economic growth: An empirical study. Economic Development and Cultural Change, 24(3), 527-538.

Jiang, X.-Z., Liu, T.-Y., \& Su, C.-W. (2014). China's marine economy and regional development. Marine Policy, 50, 227-237.

Keeble, B. R. (1988). The Brundtland report:'Our common future'. Medicine and War, 4(1), 17-25.

Nuryadin, D., Syaifudin, N., Handika, R., Setyobudi, R. H., \& Udjianto, D. W. (2016). The Economic of Marine Sector in Indonesia. Aquatic Procedia, 7, 181-186.

Pauli, G. A. (2010). The blue economy: 10 years, 100 innovations, 100 million jobs: Paradigm publications.

Samimi, A. J., Sadeghi, S., \& Sadeghi, S. (2011). Tourism and economic growth in developing countries: P-VAR approach. Middle-East Journal of Scientific Research, 10(1), 28-32. 
Smith-Godfrey, S. (2016). Defining the blue economy. Maritime Affairs: Journal of the National Maritime Foundation of India, 12(1), 58-64.

Tugcu, C. T. (2014). Tourism and economic growth nexus revisited: A panel causality analysis for the case of the Mediterranean Region. Tourism Management, 42, 207-212.

UNCHD. (2012). United Nations Conference on Human Development.

Zhang, Y.-g., Dong, L.-j., Yang, J., Wang, S.-y., \& Song, X.-r. (2004). Sustainable development of marine economy in China. Chinese Geographical Science, 14(4), 308-313. 